\title{
Integration of SRTM and TRMM date into the GIS-based hydrological model for the purpose of flood modelling
}

A. Akbari ${ }^{1, *}$, A. Abu Samah ${ }^{2}$, and F. Othman ${ }^{1}$

${ }^{1}$ Department of civil engineering, University Malaya, 50603 Kuala Lumpur, Malaysia ${ }^{2}$ Department of geography, University of Malaya, 50603 Kuala Lumpur, Malaysia * Members of Ministry of Jihad-e-Agriculture, Iran

Received: 8 January 2012 - Accepted: 29 February 2012 - Published: 16 April 2012 Correspondence to: A. Akbari (akbari_gis@yahoo.com)

Published by Copernicus Publications on behalf of the European Geosciences Union.
Integration of SRTM and TRMM date into the GIS-based hydrological model

A. Akbari et al.

\section{Title Page}

Abstract

Introduction

Conclusions

References

Tables

Figures

14

Back

Close

Full Screen / Esc

Printer-friendly Version

Interactive Discussion 


\section{Abstract}

Due to land use and climate changes, more severe and frequent floods occur worldwide. Flood simulation as the first step in flood risk management can be robustly conducted with integration of GIS, RS and flood modeling tools. The primary goal of 5 this research is to examine the practical use of public domain satellite data and GISbased hydrologic model. Firstly, database development process is described. GIS tools and techniques were used in the light of relevant literature to achieve the appropriate database. Watershed delineation and parameterizations were carried out using cartographic DEM derived from digital topography at a scale of 1:25000 with $30 \mathrm{~m}$ cell Wis uated and compared with cartographic DEM. With the assistance of statistical measures such as Correlation coefficient ( $r$ ), Nash-Sutcliffe efficiency (NSE), Percent Bias (PBias) or Percent of Error (PE). According to NSE index, SRTM-DEM can be used for watershed delineation and parameterization with $87 \%$ similarity with Topo-DEM in

15 a complex and underdeveloped terrains. Primary TRMM (V6) data was used as satellite based hytograph for rainfall-runoff simulation. The SCS-CN approach was used for losses and kinematic routing method employed for hydrograph transformation through the reaches. It is concluded that TRMM estimates do not give adequate information about the storms as it can be drawn from the rain gauges. Event-based flood modeling using HEC-HMS proved that SRTM elevation dataset has the ability to obviate the lack of terrain data for hydrologic modeling where appropriate data for terrain modeling and simulation of hydrological processes is unavailable. However, TRMM precipitation estimates failed to explain the behavior of rainfall events and its resultant peak discharge and time of peak.
HESSD

9, 4747-4775, 2012

\section{Integration of SRTM \\ and TRMM date into the GIS-based hydrological model}

A. Akbari et al.

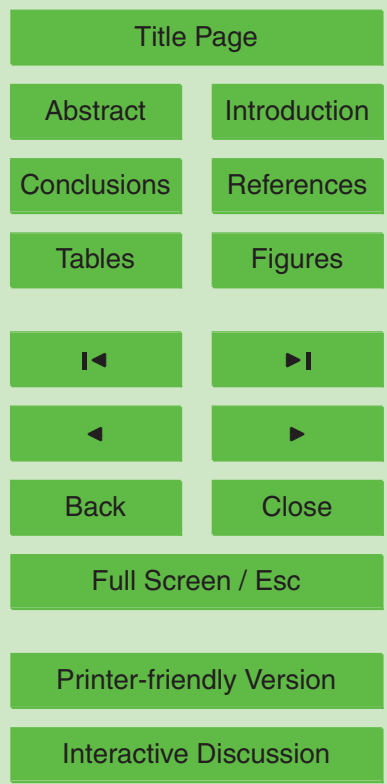




\section{Introduction}

Increasing complexity of environmental and water-resource problems require the use of modeling approaches that can incorporate knowledge from a broad range of scientific disciplines. Watershed characterization and parameterization is an important step 5 in environmental modeling. Digital terrain data is main tool for watershed modeling that provides a capability to derive watershed boundaries and associated parameters. The Digital Elevation Model (DTM) has defined as a numerical representation of the terrain. In the field of hydrology and water resources, applications of DEM have mainly focused on automate watershed segmentation, definition of drainage divides, and identification

10 of river networks. This automatic extraction of network and sub-watershed properties from the DEM represents a convenient and rapid way to parameterize a watershed (Garbrecht and Campbell, 1997). With the advent of satellite-based DEMs in fine resolution, this possibility has been provided to delineate watershed boundaries and associated parameters effectively. Several types of satellite-based DEM are available. 15 SRTM data is one of the best available free alternatives for watershed modeling. Hendricks et al. (2003a) used SRTM for estimation of channel slope in Amazon watershed. An comprehensive study conducted by Jarvis et al. (2004b) to evaluate the SRTM data against the cartographic DEM derived from topo maps at scale 1:50 000 for Honduras areas. Tulu (2005) assessed the suitability of SRTM-DEM for runoff studies and compared with ASTER-DEM. He observed that daily runoff output of SWAT model is higher when ASTER-DEM is used instead of SRTM-DEM. Hancock et al. (2006) used $90 \mathrm{~m}$ SRTM elevation data for drainage network and hydrologic modeling. They have found that $90 \mathrm{~m}$ SRTM data results in incorrect drainage network patterns and different runoff properties compare to DEM with high resolution of $10 \mathrm{~m}$. Osorio et al. (2007) compared

25 ASTER and SRTM-DEM with DEM derived from topo map at scale 1:50000 for watershed delineation. A comparative study conducted by Akbari at al. (2010) to evaluate the SRTM data against the cartographic DEM derived from topo maps at scale 1:25000 for

HESSD

$9,4747-4775,2012$

\section{Integration of SRTM \\ and TRMM date into the GIS-based hydrological model}

A. Akbari et al.

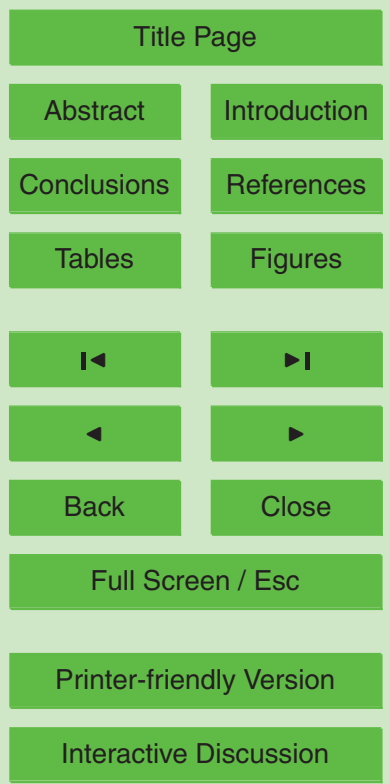


Klang watershed. They showed that visually and statistically, there are no significant differences between watershed model derived from Topo-DEM and SRTM-DEM in the hilly none-urbanized areas. Based on Nash-Sutcliff Efficiency index four investigated geometrical parameters showed a well agreement of about $97 \%, 84 \%, 72 \%$ and $99 \%$

5 for watershed area, perimeter, slope and centroid elevation respectively. However, watershed boundaries delineated from SRTM-DEM in the flat-urban areas, do not mach as good as none-urbanized areas.

Rainfall is an another important input for hydrological models. Spatial and temporal pattern of rainfall plays important role in runoff generation. Several studies have 10 shown that the spatial variability of rainfall is a major factor influencing flood formation in urban areas (Niemczynowicz, 1984; Watts and Calver, 1991; Obled et al., 1994; Bell and Moore, 2000; Faures et al., 2006). A number of studies specifically related to characterizing short-term rainfall properties have been carried out in Klang watershed (Niemczynowicz, 1987; Bacchi and Kottegoda, 1995; Desa and Niemczynowicz, 15 1996). According to Desa and Niemczynowicz (1996) the areal extension of storms in Klang watershed is limited and there is no clearly preferred direction for the storm movement and propagation is chaotic in direction. Recording raingauges are the most common source of rainfall data that is used to define the areal extension of storms in many countries. Estimating a smooth spatial distribution from noisy observations and constructing smoothed maps at locations with sparse data is performed based on geostatistical method known as Kriging. Phillips et al. (1992), Haberlandt (2006), Paciorek and Schervish (2006) and Gomez (2007) have been shown that Kriging technique provides more reliable interpolation results than any other methods. Karamouz and Araghinejad (2005) applied the Kriging method to evaluate monthly regional rainfall 25 in the central part of Iran. Thavorntam et al. (2007) indicated ordinary Kriging with spherical model performed better for interpolation of rainfall within the Thailand region. Akbari et al. (2008) conducted a research for spatial storm pattern analysis using Kriging in Klang watershed and found that the effective radius of gauges is about $3136 \mathrm{~m}$. Later Akbari et al. (2009) explained the effect of pixel size on the areal storm pattern
HESSD

$9,4747-4775,2012$

\section{Integration of SRTM \\ and TRMM date into the GIS-based hydrological model}

A. Akbari et al.

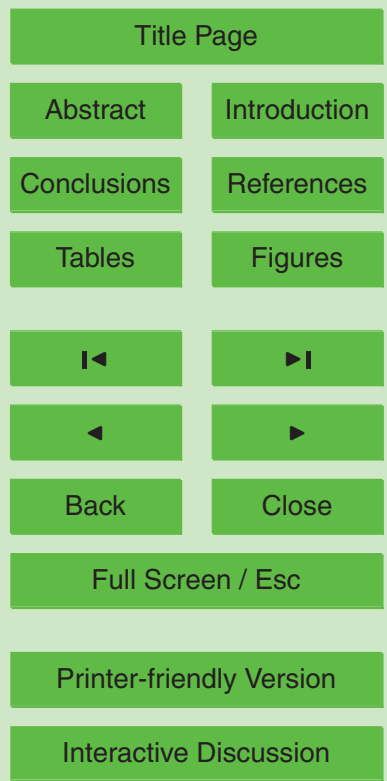


analysis using Kriging and found out that the appropriate cell size for storm pattern analysis rage from 200 to $500 \mathrm{~m}$.

However, raingauge network has no adequate coverage in many watersheds especially in developing countries. Therefore, other global source of rainfall data becomes 5 attractive for hydrological analysis such as flood modeling. With the invention of TRMM data, several researchers have tried to assess the ability of TRMM precipitation data. Recently, Varikoden et al. $(2010,2011)$ investigated the seasonal and diurnal distribution of rainfall in spatial and temporal domains over west Malaysia. They concluded that the TRMM rain rate data is enough to study the diurnal variation and spatial distribution 10 of different intensity classes in different seasons. However, they did not consider the spatio-temporal variations of storms and 3-hourly variation of TRMM estimates which have a significant influence on watershed response. The influence is evident in the different time-to-peak and shape of the correspondent flood hydrographs (Ball, 1994). Akbari at al. (2011) probed on the ability of TRMM rainfall estimates for explain the 15 Spatio-temporal pattern of severe storm over Klang watershed. They experienced that TRMM data are $35 \%$ less than actual rainfall for the investigated events. Due to coarse temporal resolution of TRMM (3-h) compare to gauge rainfall (15-min), significant uncertainty influences identifying the start and end of storm event which may change the peak volume and time to peak of flood hydrograph which is extremely important in flood forecasting systems. This research has designed to integrate the SRTM and 3-hourly TRMM data in to the hydrological model for flood modeling in Klang watershed, which frequently effects with severe storms.

\section{Objectives}

The main objectives of this research can be outlined as follow:

25 - To extend the practical use of two public domain satellite data (SRTM and TRMM) for flood simulation using public domain hydrological model (HEC-HMS and HECGeoHMS).

\section{HESSD}

9, 4747-4775, 2012

\section{Integration of SRTM \\ and TRMM date into the GIS-based hydrological model}

A. Akbari et al.

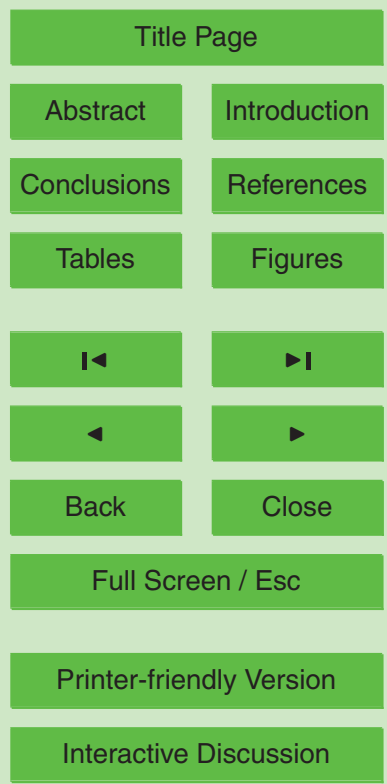


- To assess the SCS loss method with the new initial abstraction ratio (0.05) in tropic region.

HESSD

$9,4747-4775,2012$

\section{Materials and method}

The methodology followed in this research can describe in three steps:

5 In the first step, watershed boundaries and hydrologic parameters are determined using Topo-DEM and SRTM-DEM by means of HEC-GeoHMS. Spatial and temporal pattern of rainfall over Klang watershed were determined by using raingauges and TRMM precipitation data. According to Feldman (Feldman, 2000b) the SCS method as an important runoff model was used for computing the runoff depth from a rainfall - event. The SCS-CN method is one of the most popular methods for computing the volume of direct surface runoff for a given rainfall event (Mishra et al., 2008).

The HEC-HMS as an event-base data is conducted because most of the floods in Klang watershed are as result of severe storms in short time which cause flash floods. Two dataset that generated from previous stages were used for flood simulation. The 15 model was calibrated for the flood event of 6 May 2002 using HEC-HMS. By assistant of basic statistical measures the performance of SRTM and TRMM data for flood modeling are assessed. The conceptual model showed in Fig. 1, clearly demonstrates the methodology followed in this research.

\section{Study area}

20 As shown in Fig. 2, the research is carried out in upper Klang watershed located on the west coast of Peninsular Malaysia that covers the Federal Territory of Kuala Lumpur and parts of the state of Selangor.

\section{Integration of SRTM \\ and TRMM date into the GIS-based hydrological model}

A. Akbari et al.

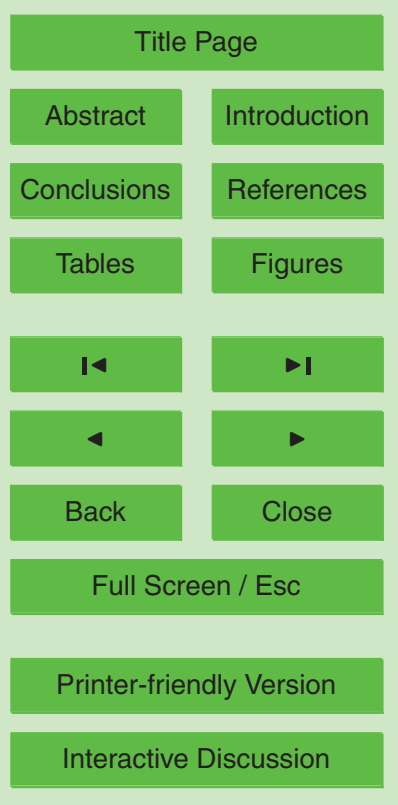




\subsection{Watershed delineation}

Delineating watershed boundary is a primary and basic step in hydrological analysis. Topo-based DEMs are most common source of watershed delineation. In previous decades, researchers have introduced several new algorithms. According to

5 Kiss (2004) the most commonly used method is Deterministic 8 (D8) introduced by O'Callaghan and Mark (1984). The procedure is based on determining flow direction from DEM.

\subsection{Raingauge data}

Gauge density in Klang watershed is much more than gauge density suggested by 10 USACE (1996). However gauge density is still less than typical rain gauge density in urban watersheds recommended by Vieux (2004) which can be exceed one gauge per 10 to $20 \mathrm{~km}^{2}$. Rainfall data for this research were collected form 29 stations maintained by DID Malaysia (see Fig. 2). We found out missing records in seven stations therefore remaining 22 stations were used for further analysis. Accumulated rainfall for storm event on 6 May 2002 and 5-days prior rainfall are provided in Table 1.

\subsection{TRMM V6 event}

The TRMM is a joint NASA/Japan satellite designed specifically to monitor rainfall and its associated latent heating in the tropics and subtropics (King et al., 2004). These standard products are processed by the TRMM Science Data and Information System (TSDIS). Radar sites located on Southern Florida, Australia (Darwin), Southeastern Texas, and the Marshall Islands are used for calibration and validation. Ground validation data are processed at Goddard Space Flight Center in cooperation with the TRMM ground validation team. Further detail about the TRMM can be found in Adler et al. (2000) and Huffman and Bolvin (2007). 3-hourly TRMM Rainfall Estimate was down-

HESSD

$9,4747-4775,2012$

\section{Integration of SRTM and TRMM date into the GIS-based hydrological model}

A. Akbari et al.

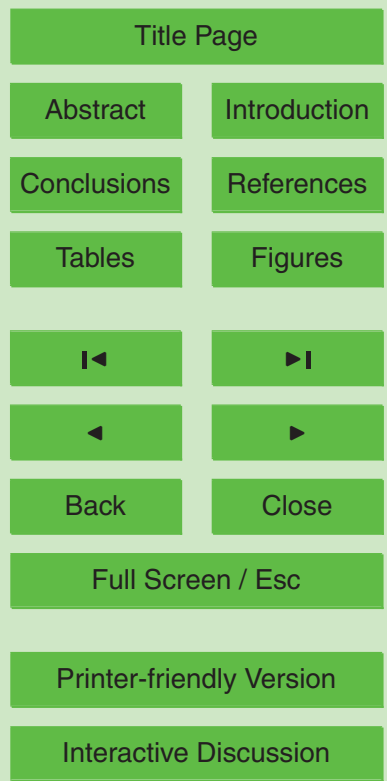


resolution of TRMM V6 data version 6 are $15^{\prime} \times 15^{\prime}$ or $\sim 27.8 \times 27.8 \mathrm{~km}$. The Klang watershed fall in five TRMM grids marked with 1, 3, 4, 5 and 6 (see Fig. 3).

To evaluate the behavior of TRMM rainfall estimates with actual data, 3-hourly and total rainfall estimates of TRMM for the selected events were compared with gauge 5 rainfall data in six cells. The cell values represents the rain depth acquired in $3 \mathrm{~h}$ starting from $1.5 \mathrm{~h}$ before and $1.5 \mathrm{~h}$ after the specified time. The hyetograph's ordinates is specified by four pairs of digits. For instance, the first ordinate of TRMM's hyetograph for event 6 May 2002 is characterized by 06-06-05-02 that denotes the Time-DayMonth-Year respectively.

\subsection{Satellite-based DEM}

SRTM provides a worldwide DEM between $60^{\circ} \mathrm{N}$ and $\mathrm{S}$ latitudes with a consistent datum. For areas outside of the conterminous United States, the original 1 arcsecond data (SRTM-1; cell size approximately $30 \mathrm{~m}$ at the equator) have resample into 3 arc-second data (SRTM-3) by averaging (JPL/NASA, 2006). The 3-arc-second

15 (approx. $90 \mathrm{~m}$ at the equator) SRTM dataset version 2 (known as finished data) that provided by HydroSHEDS (Hydrological data and maps based on SHuttle Elevation Derivatives at multiple Scales) was used for delineation of Klang watershed boundaries. HydroSHEDS data are free for non-commercial use (Lehner et al., 2006a). Raw data were downloaded from the from HydroSHEDS website made by US Geological 20 Survey (2008) (see http://hydrosheds.cr.usgs.gov/). The HydroSHEDS is an internetbased data center that provides pre-processed SRTM elevation data and other products.

\section{Result and discusion}

Watershed delineation and parameterization was performed using Topo-DEM and
HESSD

$9,4747-4775,2012$

\section{Integration of SRTM \\ and TRMM date into the GIS-based hydrological model}

A. Akbari et al.

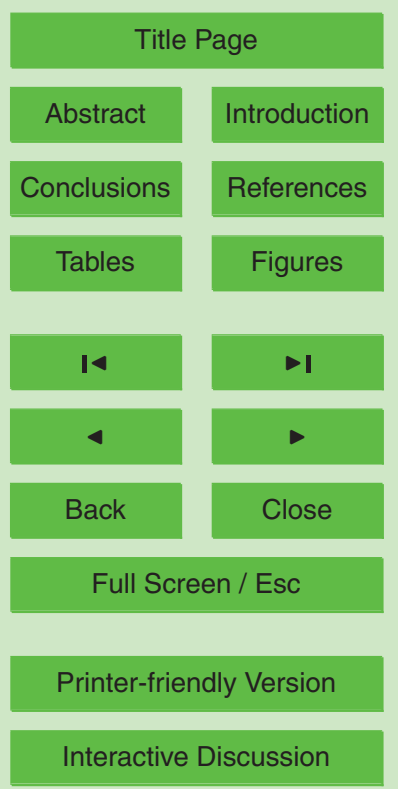


concentration of two DEM-derived datasets in the vicinity of the identity lines, imply on relatively high similarity of two dataset when comparison is made based on the 31 sub-watershed. Statistical measures listed in Table 1 for 31 sub-watersheds (see Fig. 4). A good agreement is found between two DEM-derivatives. Overall agreement 5 between DEM-derivatives of Topo-DEM and SRTM-DEM is about $0.90,0.95$ and $87 \%$ for $R^{2}, r$ and NSE respectively that is acceptable level of agreement.

There is a close correlation ( $r=0.99)$ between observed and TRMM estimates for the total rainfall depth. In spite of that, there is no significant correlation for temporal pattern of storms. In other word, as shown in Fig. 5 hyetograph derived from TRMM do not match with observed hyetographs of selected events except for event 6 May.

\subsection{Satellite-based flood modeling with HEC-HMS}

The Hydrologic Engineering Center (HEC) within the US Armey Corps of Engineers (USACE) is one the pioneer institutions that provided a numerical model with capability to simulate the surface runoff response of a watershed to precipitation by representing 15 the dendrite drainage with interconnected hydrologic and hydraulic components (Feldman et al., 1981). It began with develop of a flood hydrograph package named HEC-1 by Beard and other staff members of HEC in 1961 (Feldman et al., 1981). New generation of HEC-1 is called the HMS (Hydrologic Modeling System) which is a numerical model that provides a large set of methods to simulate watershed runoff, infiltration 20 losses, river flood routing, and water-control structure behavior, thus predicting flow and timing (Ford et al., 2008). The theory and algorithm of the used methods are well documented in the HEC-HMS's Technical Reference Manual (Feldman, 2000b), Application Guide (Ford et al., 2008) and User's manual (Scharffenberg and Fleming, 2008). Most of the models included in HEC-HMS are event-based models. HEC-HMS 25 is considered as a standard model in the private sector and government organizations for flood-runoff modeling. It has been used in many research projects (Akbari, 1998; Cunderlik and Simonovic, 2004; Redfearn, 2005; Knebla et al., 2005; Robayo, 2005; Lowrey, 2006; Verdi, 2007; Ahn, 2007). The model has been widely used for design 4755

\section{HESSD}

$9,4747-4775,2012$

\section{Integration of SRTM \\ and TRMM date into the GIS-based hydrological model}

A. Akbari et al.

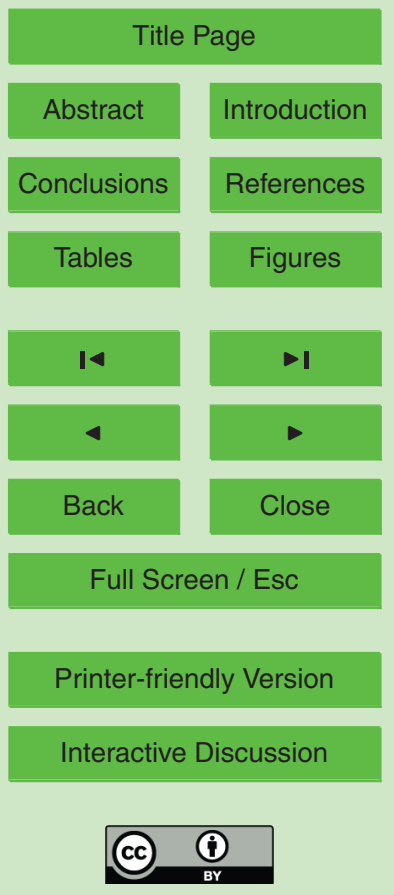


of drainage systems and quantifying the effect of land use change on floods in the US (Bekoe, 2005). HEC-HMS model was developed for Klang valley as shown in Fig. 6.

To achieve the objective of this research five scenarios were organized as follows:

\subsubsection{Run1: Running for Topo-DEM derived parameters and rain gauges data}

5 The HEC-HMS model was set to DEM-derivatives of Topo-DEM. The model was set to SCS method for calculating the losses and required data were interred. In this stage, traditional SCS equation with $\mathrm{CN}$ value from Table 2 (remarked in Table 2 with $\mathrm{CN}_{0.2}$ ) was used for estimation of losses. Kinematic wave routing method was used for flood routing and relevant parameters were used from existing reports. Meteorological model

10 was set for flood event 6 May and corresponding rainfall hyetographs were specified for each gauging station. Starting and ending of rainfall-runoff process is set in control specification menu. Corresponding observed stream flow data were interred to the model. Storage-Discharge function for Klang Gate and Batu dams were specified in Paired Data management menu. Time interval was set for 15 min for both rainfall and stream flow data. The base flow at stream flow stations were set to "no base flow" but the base flow have been subtracted from observed flow hydrographs at those stations. To track the behavior of the model for different scenarios, the flood hydrograph at Sulaiman Bridge is discussed.

A significant correlation coefficient of 0.93 is existed between observed and calcu20 lated hydrograph (see Fig. 7). Based on Nash-Sutcliffe efficiency simulated hydrograph can explain the shape of observed hydrograph by $86 \%$. Surprisingly, time of peak for simulated and observed flood event completely match at Sulaiman Bridge station.

\subsubsection{Run2: Running for modified CN}

The Initial Abstraction ratio $\left(I_{\alpha} / S\right.$, or $\left.\lambda\right)$ in the SCS method was substituted. Hawkins et al. (2002a) have investigated this assumption using event rainfall-runoff data from several hundred plots, and $\lambda$ values determined by two different methods. Results
HESSD

9, 4747-4775, 2012

\section{Integration of SRTM \\ and TRMM date into the GIS-based hydrological model}

A. Akbari et al.

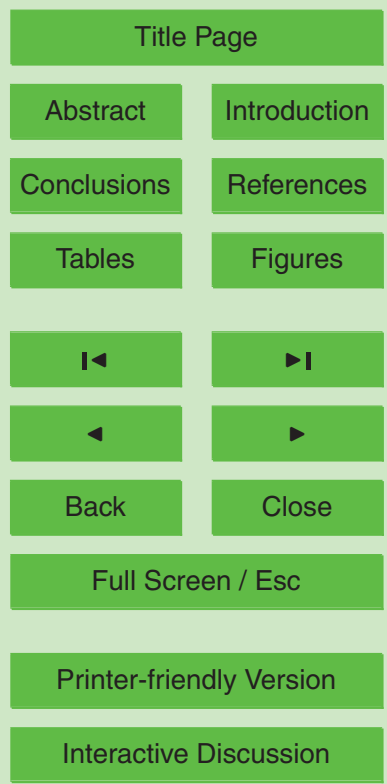


indicated that $\lambda$ value of about 0.05 gives a better fit to the data and gives more appropriate results for use in runoff calculations. The effects of this change are shown in terms of calculated runoff depth and hydrograph peaks, CN definition, and in soil moisture accounting. In this run, loss estimation parameters including $\mathrm{CN}$ and $I_{\alpha}$ was 5 changed to new $\mathrm{CN}_{0.5}$ and $I_{\alpha(0.05)}$ in HMS model and the other components of the model was remained the same. As expected the flood simulation results was significantly improved. A perfect simulation for Peak flood, time to peak and volume were found for this event. Flood hydrograph at Sulaiman Bridge is presented in Fig. 7. The Nash-Sutcliffe efficiency is decreased from $86 \%$ to $85 \%$.

\subsubsection{Run3: Running for SRTM-derived sub-watershed area}

Run2 it is considered as an optimized flood simulation and therefore it can be considered as reference for impact assessment of investigated parameters. To assess the performance of SRTM-derivatives, the sub-watershed area derived from SRTMDEM were substituted with the sub-watershed areas derived from Topo-DEM in the 15 HEC-HMS model. The other parameters were remained the same. Computed flow hydrograph for sub-watershed. Observed and computed flood hydrograph at Sulaiman Bridge denotes that time of peak does not change but the peak flow is decreased from $360.8\left(\mathrm{~m}^{3} \mathrm{~s}^{-1}\right)$ to $316.5\left(\mathrm{~m}^{3} \mathrm{~s}^{-1}\right)$ (see Fig. 9). The NSE is significantly decreased from $85 \%$ to $78 \%$ and gives $11 \%$ under estimate for peak discharge. The RMSE increased 20 from 37 to 45 .

It is important to know that the total drainage area derived from Topo-DEM and SRTM-DEM at Sulaiman Bridge is $464.6 \mathrm{~km}^{2}$ and $460.5 \mathrm{~km}^{2}$ respectively. This means that Topo-DEM depict watershed area about $1 \%$ larger than SRTM-DEM at that particular point. Whereas computed peak flood is decreased about, $11 \%$ when watershed areas derived from SRTM-DEM is served. It is may be due to existing discrepancies between two DEM-derived watershed boundaries which affect other input parameters such as rainfall, impervious area, watershed slope etc. Moreover, the total volume of

HESSD

$9,4747-4775,2012$

\section{Integration of SRTM \\ and TRMM date into the GIS-based hydrological model}

A. Akbari et al.

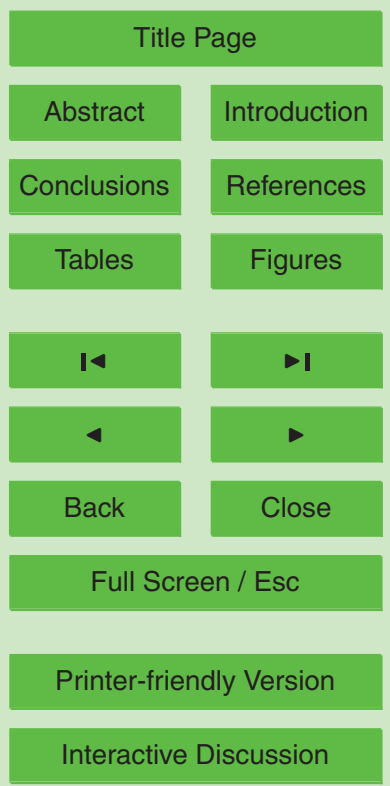


the outflow is well simulated when watershed area derived from SRTM-DEM is served by HEC-HMS.

\subsubsection{Run4: Running for Topo-derived sub-watershed area and TRMM estimates}

5 Klang watershed lies on six TRMM cells with uniform rainfall estimates in each cell. To account the temporal and spatial pattern of event of 6 May, TRMM cells was considered as regular rain gauge network containing six raingauges named Cell1, Cell2, Cell3, Cell4, Cell5 and Cell6 (see Fig. 2). Temporal pattern was defined with 3-h time interval for each gauge. With overlying the TRMM grid on DEM-derived sub-watershed boundaries, the raingauges that affect the sub-basins are specified. The other parameters was remained the same as Run2. Flood hydrograph for Run4 at Sulaiman Bridge are presented in Fig. 10. Percent of error in peak flow gives $60 \%$ under estimate at Sulaiman Bridge.

In addition time of peak shifts from 15:30 LT (observed) to 18:00 LT with $2.5 \mathrm{~h}$ de-

\subsubsection{Run5: Running for SRTM-derived sub-watershed area and TRMM estimates}

Simultaneous use of SRTM-derived areas and TRMM rain estimate are employed in Run5. Peak discharge at Sulaiman Bridge is reduced from $612.9 \mathrm{~m}^{3} \mathrm{~s}^{-1}$ to $134.2 \mathrm{~m}^{3} \mathrm{~s}^{-1}$ that denote high percent of error in estimation of peak flow (see Fig. 11). However, the percent of error in total volume of outflow is about $15 \%$ under estimate. Moreover, time of peak and shape of hydrograph do not match with the observed hydrograph. Percent
HESSD

$9,4747-4775,2012$

\section{Integration of SRTM and TRMM date into the GIS-based hydrological model}

A. Akbari et al.

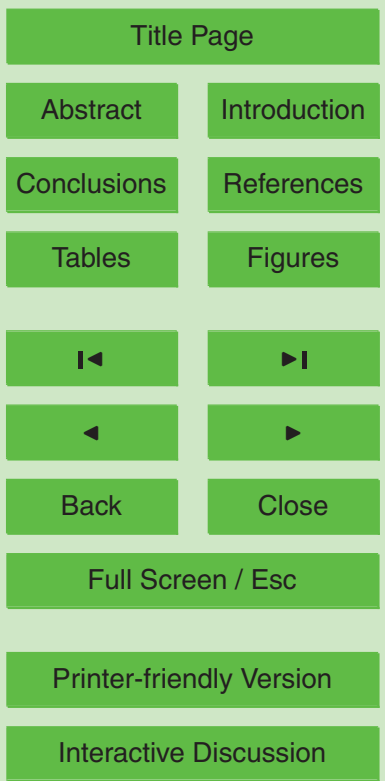


of error in peak discharge indicates $60 \%$ under estimate for simulated peak flow at Sulaiman Bridge.

\section{Conclusions}

- SRTM-DEM provided competitive results for watershed delineation, stream delineation and physical parameters such as area, slope, lag time and mean elevation specifically in non-urbanized areas with rugged topography. Moreover, SRTMDEM is very coast effective and time saving in hydrological researches. However, SRTM-DEM should be used with cousin in flat urban areas.

- TRMM estimates exhibit a rough estimation about spatial and temporal pattern of observed storms. Therefore it do not draw adequate information about the spatial variation of localized storms in tropic regions as it can be drawn from the dense rain gauges network of Klang watershed. However, TRMM estimates are a useful source of data for the area with sparse gauge density with distance longer than $30 \mathrm{~km}$. TRMM estimates depict the rainfall depth under estimated (about $35 \%$ ) than the actual value measured at the rain gauges. Moreover, with coarse temporal resolution of TRMM cannot capture the actual pattern of rainfall hyetograph and therefore the values and time of peak discharge.

- SRTM-DEM is a trustable source of data for flood simulation particularly in nonurbanized areas. Nevertheless, TRMM hyetograph provide underestimated result (about $60 \%$ ) for peak discharge and cannot simulated the shape of hydrograph. Therefore, TRMM estimates are not suitable source of data for flash flood study that mostly occurs in short time and characterized by localized storms. However, integrating TRMM and SRTM data give a reasonable estimation for volume of the floods in midsize watersheds.

- Flood hydrograph is best calibrated for peak discharge with the modified ratio of initial abstraction to maximum potential retention $(\lambda)$ in SCS model. Therefore, it

HESSD

9, 4747-4775, 2012

\section{Integration of SRTM \\ and TRMM date into the GIS-based hydrological model}

A. Akbari et al.

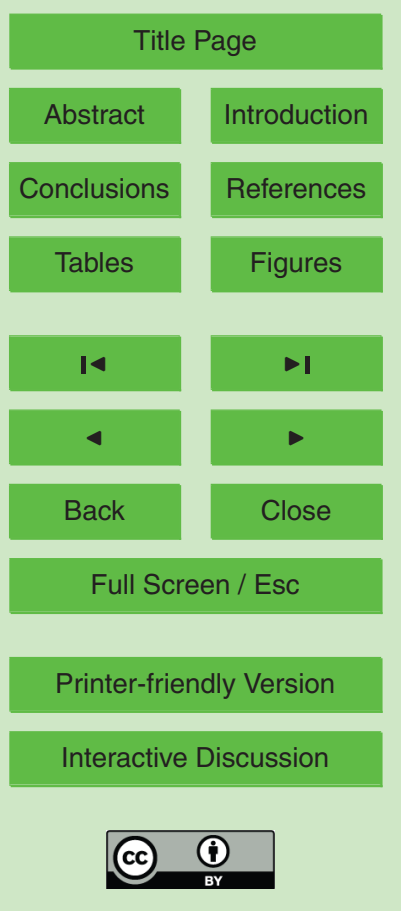


is recommended to use modified ratio for flood simulation and other applications of SCS method in the tropic region of peninsular Malaysia and similar regions.

Acknowledgements. This paper was founded by Department of Civil Engineering at the University of Malaya in Malaysia. We Acknowledge NASA for providing free TRMM data and DID 5 Malaysia for providing raingauge data.

\section{References}

Adler, R., Negri, A., and Hakkarinen, I.: Tropical rainfall distributions determined using TRMM combined with other satellite and rain gauge information, J. Appl. Meteorol., 39, 2007-2023, 2000.

10 Akbari, A., Othman, F., and Samah, A. A.: Spatial Storm Pattern Analysis Using Kriging, Case Study; upper Klang River Basin, Malaysian Science and technology Congress (MSTC2008), KLCC, Kuala Lumpur, Malaysia, 2008.

Akbari, A., Samah, A. A., and Othman, F.: Effect of Pixel Size on the Areal Storm Pattern Analysis using Kriging, J. Appl. Sci., 9, 3707-3714, 2009.

15 Bacchi, B. and Kottegoda, A. N. T.: Identification and calibration of spatial correlation patterns of rainfall, J. Hydrol., 165, 311-348, 1995.

Ball, J. E.: The influence of storm temporal patterns on catchment response, J. Hydrol., 158, 285-303, 1994.

Bell, V. A. and Moore, R. J.: The sensitivity of catchment runoff models to rainfall data at different spatial scales, Hydrol. Earth Syst. Sci., 4, 653-667, doi:10.5194/hess-4-653-2000, 2000.

Bitew, M. and Gebremichael, M.: Evaluation Through Independent Measurements: Complex Terrain and Humid Tropical Region in Ethiopia, Satellite Rainfall Applications for Surface Hydrology, Springer, New York, 205-214, 2010.

25 Desa, M. N. and Niemczynowicz, J.: Temporal and spatial characteristics of rainfall in Kuala Lumpur, Malaysia, Atmos. Res., 42, 263-277, 1996.

Earls, J. and Dixon, B.: Spatial Interpolation of Rainfall Data Using ArcGIS: Comparative Study, in: ESRI User Conference 2007 San Diego, ESRI, California, USA, 2007.

Faures, J.-M., Goodrich, D. C., and Woolhiser, D. A.: Impact of small-scale spatial rainfall variability on runoff modeling, Nord. Hydrol., 37, 261-275, 2006.
HESSD

9, 4747-4775, 2012

\section{Integration of SRTM \\ and TRMM date into the GIS-based hydrological model}

A. Akbari et al.

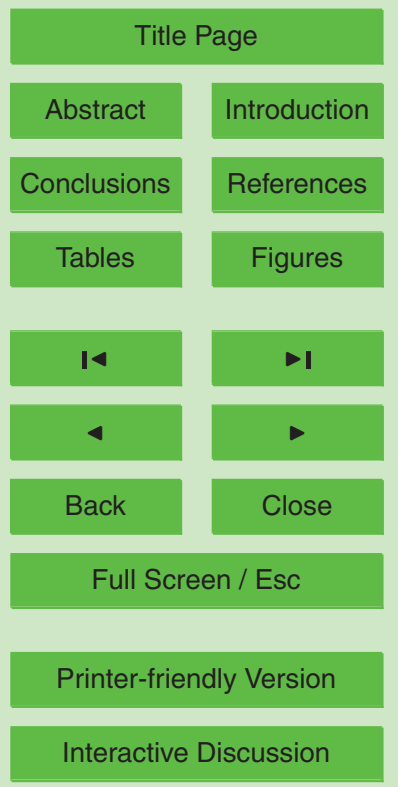


Gomez, M. R. S.: Spatial and temporal RAinfall Gauge Data Analaysis and Validation with TRMM Microwave Radiometer surface Rainfall Retrievals, Master, International Institue fro Geo-information Science and Earth Observation, ITC, The Netherlands, 2007.

Goovaerts, P.: Geostatistical approach for incorporating elevation into the spatial interpolation of rainfall, J. Hydrol., 228, 113-129, 2000.

Haberlandt, U.: Geostatistical Interpolation of Hourly Precipitation from Rain Gauges and Radar or a large-Scale Extrem Rainfall event, J. Hydrol., 332, 144-157, 2006.

Huffman, G. and Bolvin, D.: Real-time TRMM multi-satellite precipitation analysis data set documentation, Laboratory for Atmospheres, NASA Goddard Space Flight Center and Science

$10 \quad$ Systems and Applications, Inc., p. 26, 2007.

Karamouz, M. and Araghinejad, S.: Advanced hydrology, Amirkabir University Press, 2005.

King, M. D., Closs, J., Wharton, S., and Myers, M.: EOS Data Products Handbook, University of Tehran, Tehran, Iran, 2004.

Kobold, M.: Hydrological Modelling of Floods, in: Advances in Urban Flood Management, edited by: Ashley, R., Garvin, S., Pasche, E., V, A., and Zevenbergen, C., Taylor \& Francis, 2007.

NASA: Readme for TRMM Product 3B42 (V6), http://disc.sci.gsfc.nasa.gov/precipitation/ documentation/TRMM_README/TRMM_3B42_readme.shtml (last access: 5 June 2010), 2009.

20 Niemczynowicz, J.: Investigation of the Influence of Rainfall Movement on Runoff Hydrograph, Nord. Hydrol., 15, 71-84, 1984.

Niemczynowicz, J.: Storm tracking using rain gauge data, J. Hydrol., 93, 135-152, 1987.

Obled, C., Wendling, J., and Beven, K.: The sensitivity of hydrological models to spatial rainfall patterns: an evaluation using observed data, J. Hydrol., 159, 305-333, 1994.

Paciorek, C. and Schervish, M.: Spatial modelling using a new class of nonstationary covariance functions, Environmetrics, 17, 483-506, 2006.

Phillips, D. L., Dolph, J., and Marks, D.: A comparision of Geostatistical Procedures fro spatial analysis of Precipitation in Mountainous terrain, Joricult. Agr. Forest Meteorol., 58, 119-141, 1992.

30 Thavorntam, W., Wattanakij, N., and Mongkolsawat, C.: Estimation of rainfall spatial interpolation methods in North-East Thailand, in: Asian Conference on Remote Sensing (ACRS 2007), 12-6 November 2007 (PWTC), Kuala Lumpur, Malaysia, 2007.
HESSD

9, 4747-4775, 2012

\section{Integration of SRTM \\ and TRMM date into the GIS-based hydrological model}

A. Akbari et al.

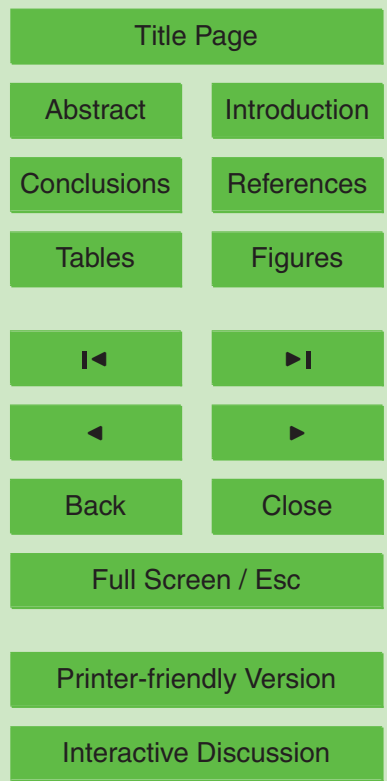


USACE: Hydrologic Aspects of Flood Warning - Preparedness Programs, in: Engineers, Technical Letter, edited by: U. S. A. C. O., U.S. Army Corps of Engineers, Washington, DC, 1996.

Varikoden, H., Samah, A. A., and Babu, C. A.: Spatial and temporal characteristics of rain intensity in the peninsular Malaysia using TRMM rain rate, J. Hydrol., 387, 8, 2010.

5 Varikoden, H. B. P., Samah, A. A., and Babu, C. A.: Seasonal variation of rainfall characteristics in different intensity classes over Peninsular Malaysia, J. Hydrol., 404, 9, 2011.

Vieux, B. E.: Distributed Hdyrologic Modeling Using GIS, Kluwer Academic Publishers, 2004.

Watts, L. G. and Calver, A.: Effects of Spatially-Distributed Rainfall on Runoff for a Conceptual Catchment, Nord. Hydrol., 22, 1-14, 1991.

HESSD

9, 4747-4775, 2012

\section{Integration of SRTM and TRMM date into the GIS-based hydrological model}

A. Akbari et al.

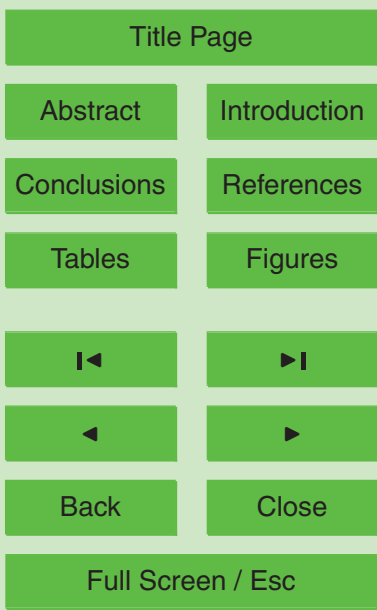

Printer-friendly Version

Interactive Discussion 


\section{HESSD}

9, 4747-4775, 2012

\section{Integration of SRTM and TRMM date into the GIS-based hydrological model}

A. Akbari et al.

Table 1. Accumulated rainfall for investigated storm event on 2002.

\begin{tabular}{|c|c|c|c|c|c|c|c|c|c|c|c|c|c|c|c|c|c|c|c|c|c|c|c|c|}
\hline 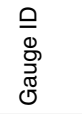 & 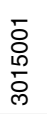 & $\begin{array}{l}\bar{\delta} \\
\frac{0}{0} \\
\frac{0}{0}\end{array}$ & $\begin{array}{l}\text { ㅇ } \\
\frac{0}{0} \\
\frac{\text { }}{0}\end{array}$ & 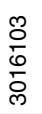 & 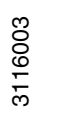 & $\begin{array}{l}\text { ঠ் } \\
\frac{8}{0} \\
\frac{0}{n}\end{array}$ & $\begin{array}{l}0 \\
8 \\
\frac{0}{\infty} \\
\frac{\pi}{m}\end{array}$ & $\begin{array}{l}\text { N } \\
\frac{0}{0} \\
\frac{0}{m}\end{array}$ & $\frac{\text { 옹 }}{\frac{\Gamma}{\infty}}$ & 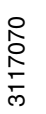 & $\frac{\overline{0}}{\frac{5}{\pi}}$ & $\frac{}{\frac{N}{}}$ & $\frac{\text { J }}{\frac{D}{N}}$ & $\begin{array}{l}\text { ঠे } \\
\text { ঠ্ } \\
\text { స్ }\end{array}$ & 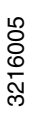 & $\begin{array}{l}\text { N } \\
\frac{D}{N} \\
\frac{N}{N}\end{array}$ & $\begin{array}{l}\text { O্ర } \\
\frac{N}{N} \\
\text { N }\end{array}$ & 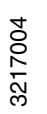 & $\frac{\text { 옹 }}{\frac{8}{\sim}}$ & $\frac{\bar{\delta}}{\frac{\delta}{p}}$ & 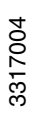 & 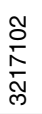 & $\begin{array}{l}\text { ฮ్ } \\
\stackrel{\mathbb{\Xi}}{\Sigma}\end{array}$ & 훙 \\
\hline$R \mathrm{~mm}$ & 30 & 51 & 12 & * & 59.5 & 60.5 & 39 & 45 & 24 & 63 & 2.5 & 15 & 30 & 16 & 5 & 42 & 29 & 57 & 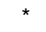 & 0 & 27 & . & 31.8 & 20.5 \\
\hline 5DPR & 33 & 20 & 20 & * & 55.5 & 58 & 33 & 32 & 24 & 30 & 60 & 27 & 35 & 33 & 13 & 26 & 23 & 14 & * & 71 & 10 & * & 33.1 & 17.3 \\
\hline
\end{tabular}

\section{Title Page}

\section{Abstract}

Conclusions

Tables

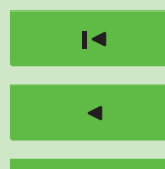

Back

Full Screen / Esc

Printer-friendly Version

Interactive Discussion 


\section{HESSD}

9, 4747-4775, 2012

\section{Integration of SRTM and TRMM date into the GIS-based hydrological model}

Table 2. Evaluation of two DEM-derived parameters by statistical measures.

\begin{tabular}{|c|c|c|c|c|c|}
\hline DEM derivatives & RMSE & $R^{2}$ & $r$ & NSE & Bias \\
\hline Perimeters & 7053 & 0.732 & 0.856 & 0.644 & -8.30 \\
\hline Mean elevation & 5.73 & 0.997 & 0.998 & 0.998 & 0.49 \\
\hline River slope & 0.004 & 0.952 & 0.976 & 0.933 & -12.63 \\
\hline Longest flow length & 1525 & 0.801 & 0.895 & 0.766 & -1.99 \\
\hline SCS curve number & 1.30 & 0.994 & 0.997 & 0.993 & 0.42 \\
\hline Lag time & 0.32 & 0.950 & 0.975 & 0.797 & -0.82 \\
\hline Watershed slope & 4.73 & 0.848 & 0.921 & 0.840 & 12.06 \\
\hline Watershed area & 3.57 & 0.956 & 0.978 & 0.954 & -1.31 \\
\hline \multicolumn{2}{|c|}{ Overall agreement } & 0.90 & 0.95 & 0.87 & \\
\hline
\end{tabular}

A. Akbari et al.

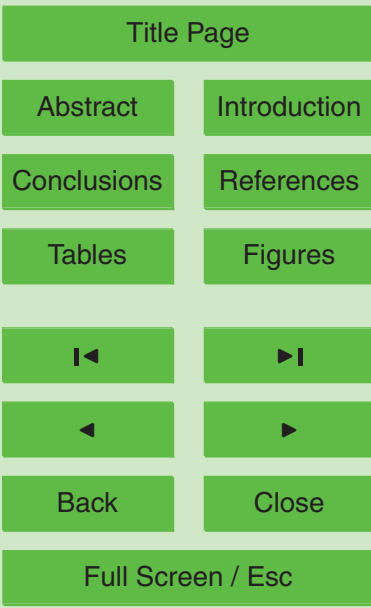

Printer-friendly Version

Interactive Discussion 


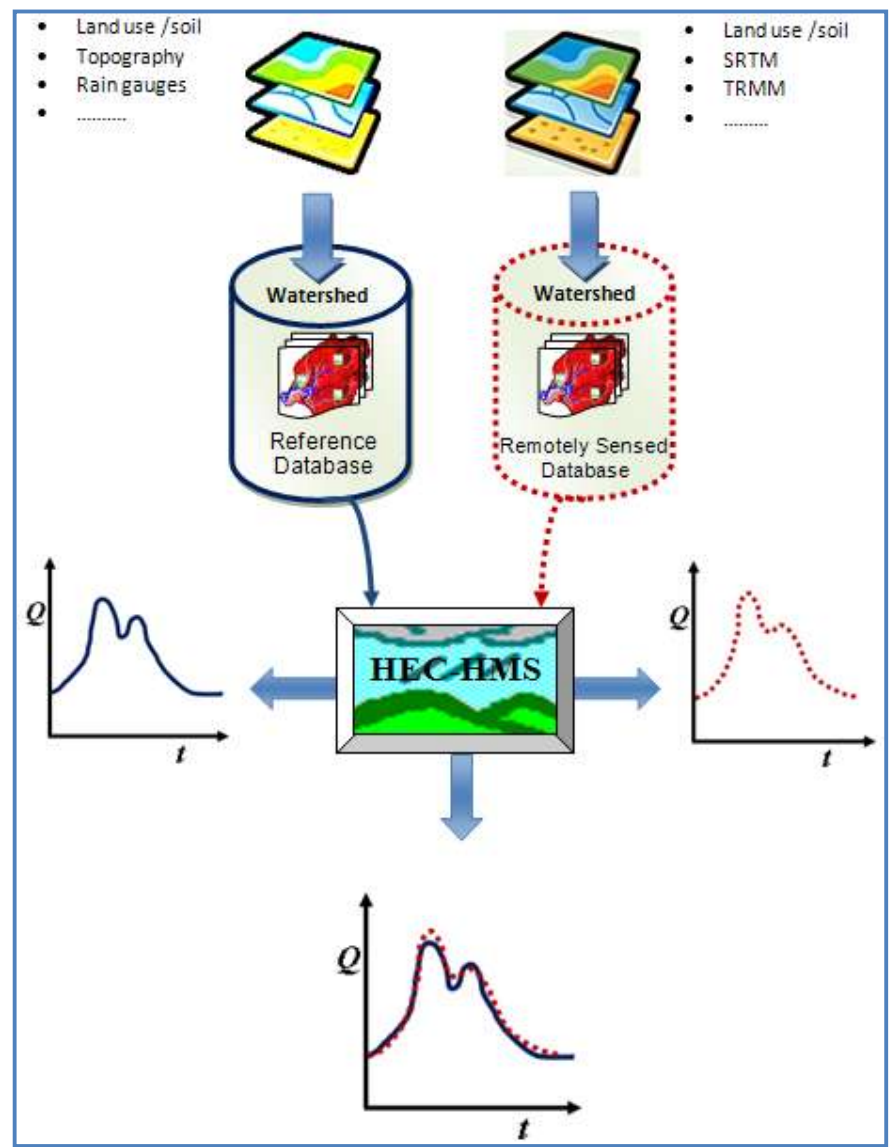

Fig. 1. Conceptual representation of GIS-based hydrological simulation showing methodology followed in the research.

\section{HESSD}

9, 4747-4775, 2012

\section{Integration of SRTM and TRMM date into the GIS-based hydrological model}

A. Akbari et al.

Title Page

Abstract

Introduction

Conclusions

References

Tables

Figures

14

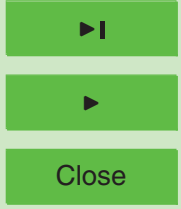

Back

Full Screen / Esc

Printer-friendly Version

Interactive Discussion 


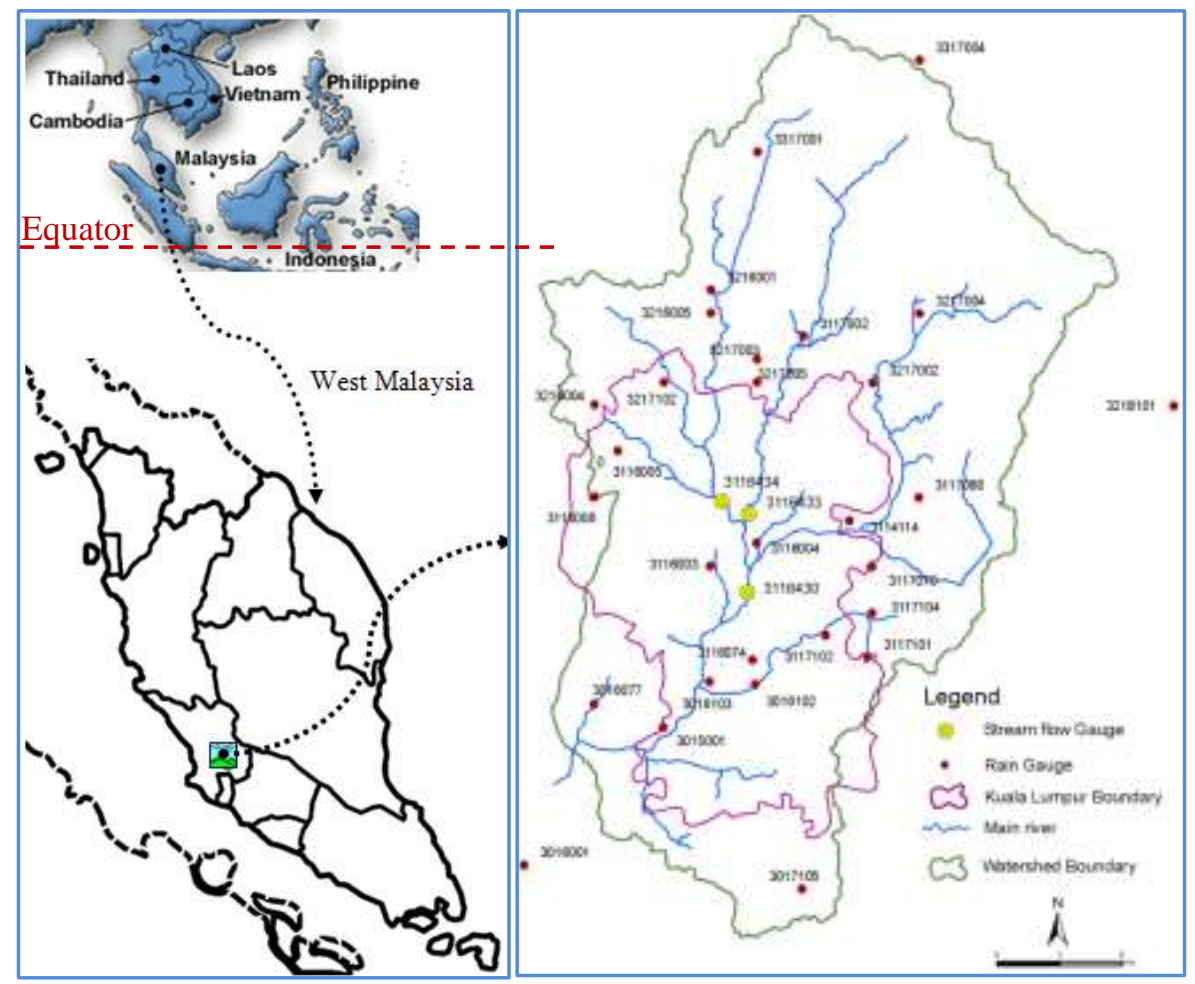

\section{HESSD}

9, 4747-4775, 2012

Integration of SRTM and TRMM date into the GIS-based hydrological model

A. Akbari et al.

\section{Title Page}

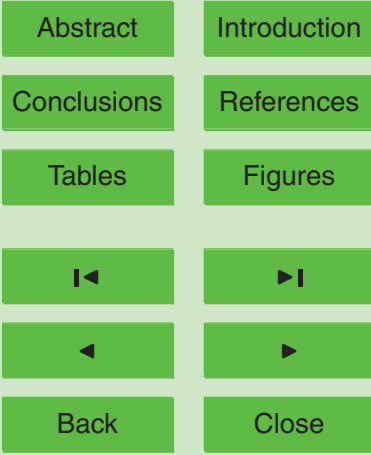

\section{Full Screen / Esc}

Fig. 2. Study area and used rainfall stations.

Printer-friendly Version

Interactive Discussion 


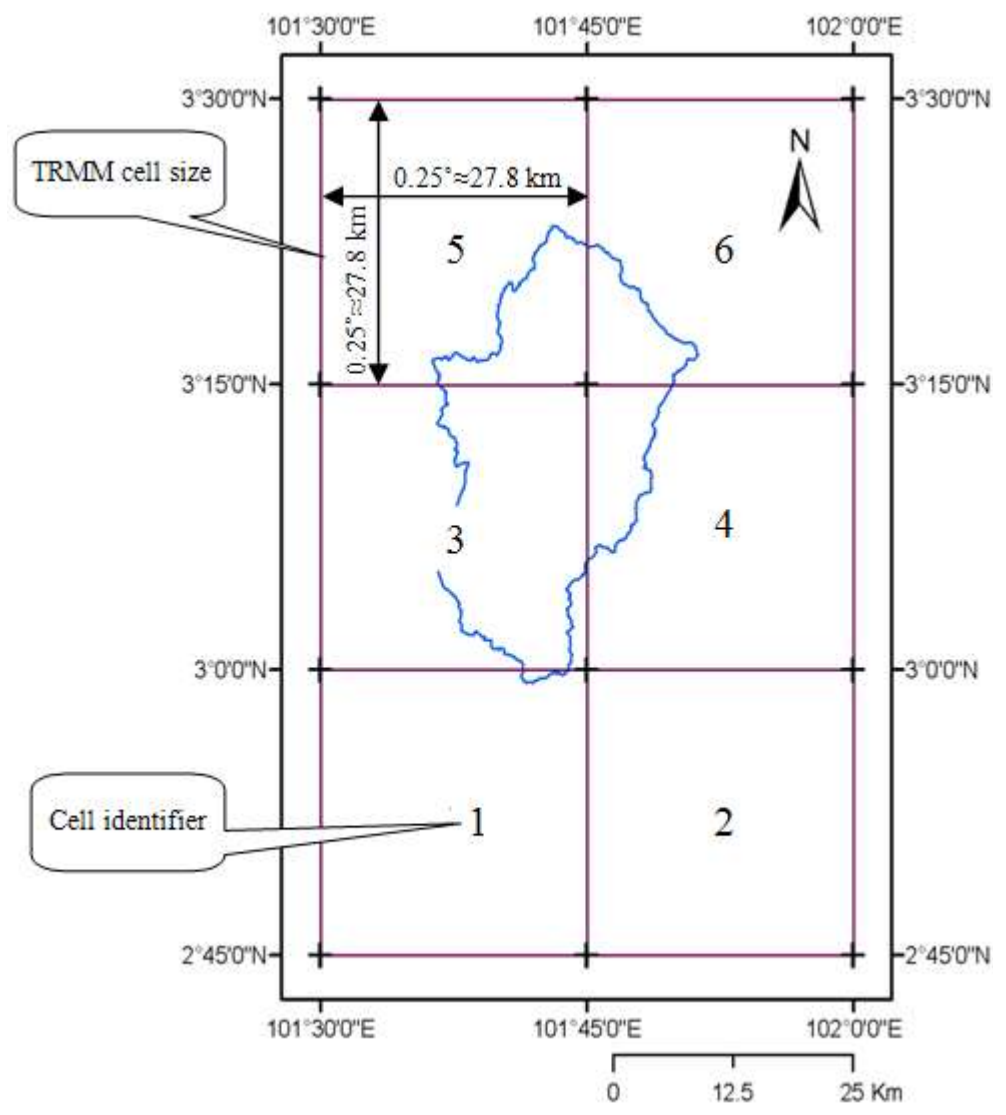

HESSD

9, 4747-4775, 2012

\section{Integration of SRTM and TRMM date into the GIS-based hydrological model}

A. Akbari et al.

Title Page

Abstract

Conclusions

Tables

14

4

Back

Full Screen / Esc

Printer-friendly Version

Interactive Discussion 


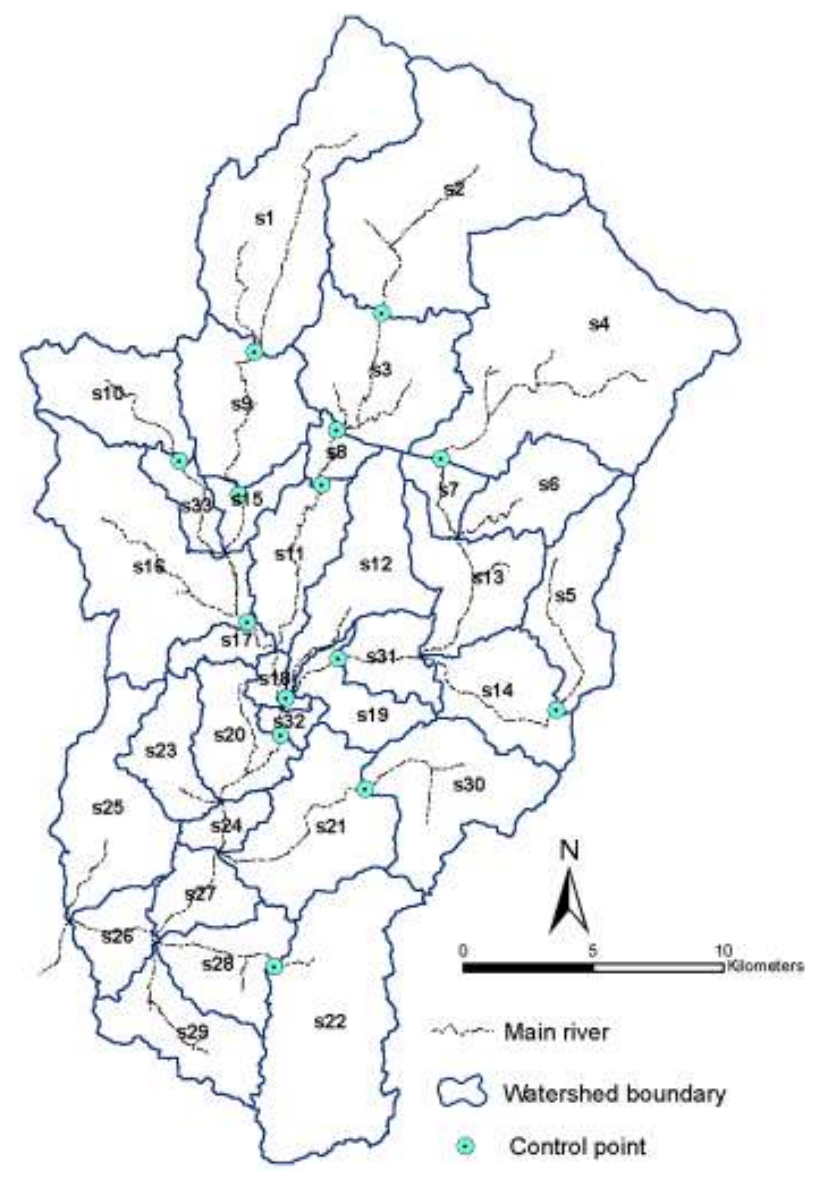

HESSD

9, 4747-4775, 2012

\section{Integration of SRTM and TRMM date into the GIS-based hydrological model}

A. Akbari et al.

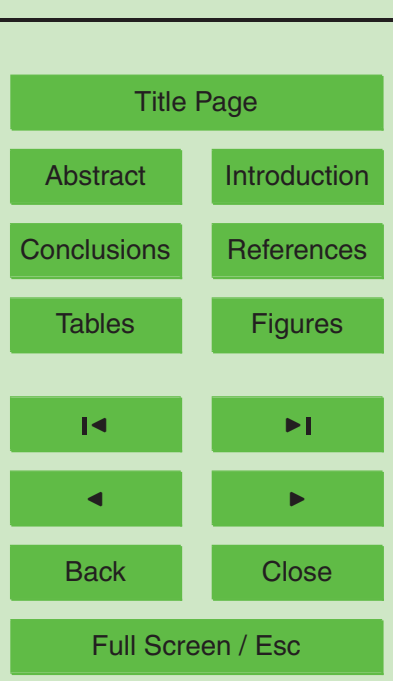

Fig. 4. Sub-watershed boundaries derived from Topo-DEM.

Printer-friendly Version

Interactive Discussion 


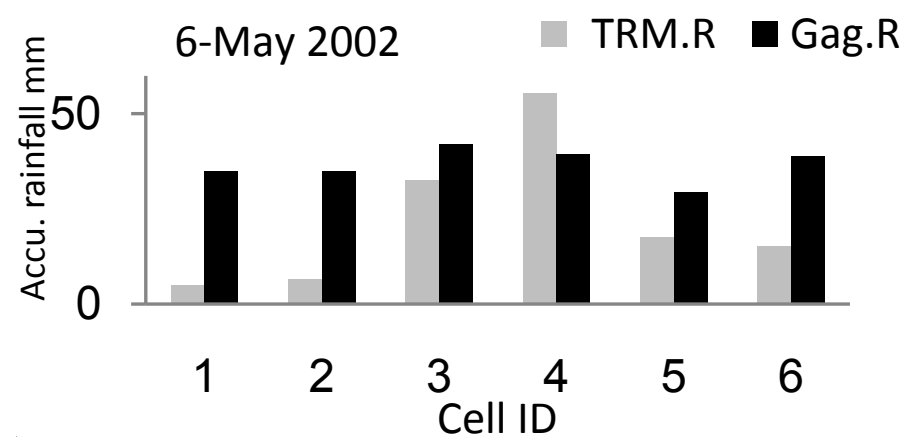

HESSD

9, 4747-4775, 2012

\section{Integration of SRTM and TRMM date into the GIS-based hydrological model}

A. Akbari et al.

Fig. 5. Spatial distribution of total rain depth over the six TRMM cells.

Title Page

Abstract

Introduction

Conclusions

References

Tables

Figures

14

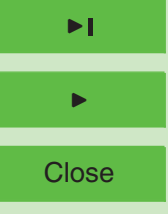

Back

Full Screen / Esc

Printer-friendly Version

Interactive Discussion 


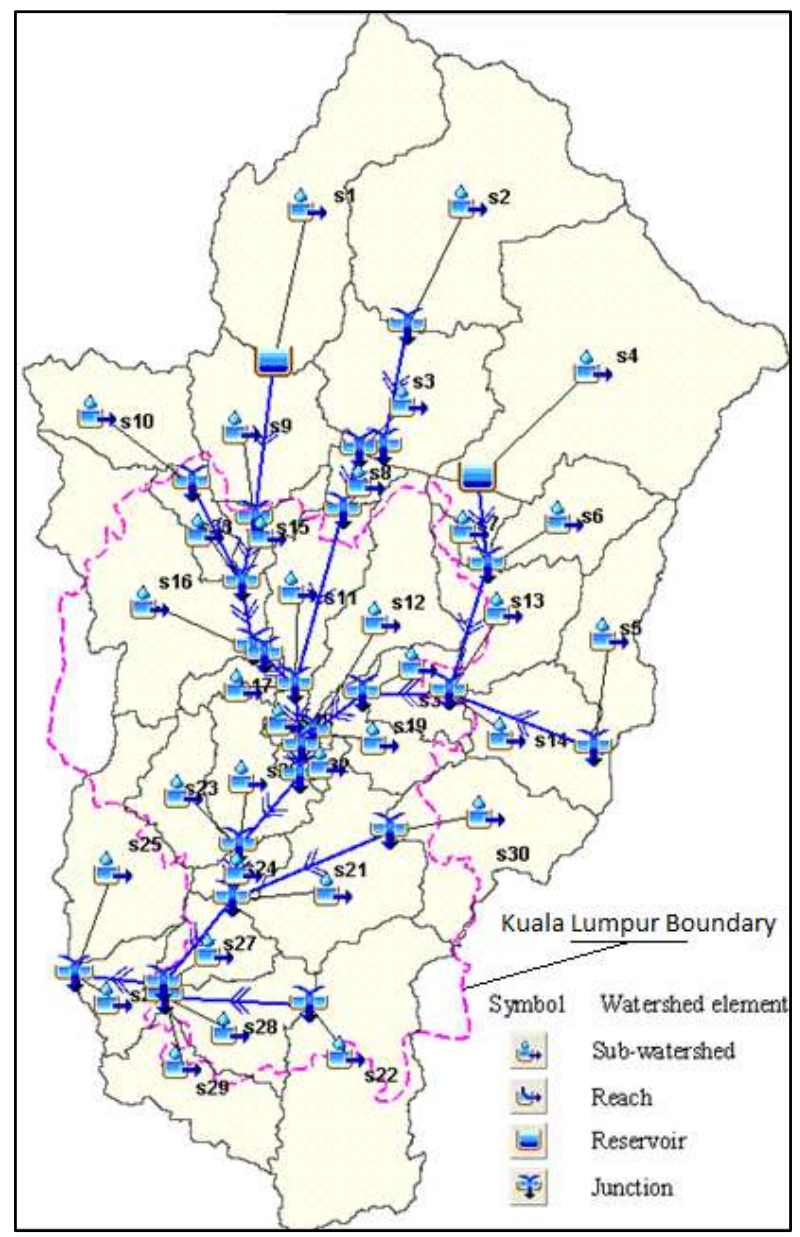

HESSD

9, 4747-4775, 2012

\section{Integration of SRTM and TRMM date into the GIS-based hydrological model}

A. Akbari et al.

Title Page

\section{Abstract}

Conclusions

\section{Tables}

14

4

Back

Full Screen / Esc

Printer-friendly Version

Interactive Discussion

Fig. 6. HEC-HMS model for Klang watershed. 
Junction "Suliman SFS" Results for Run "6may"

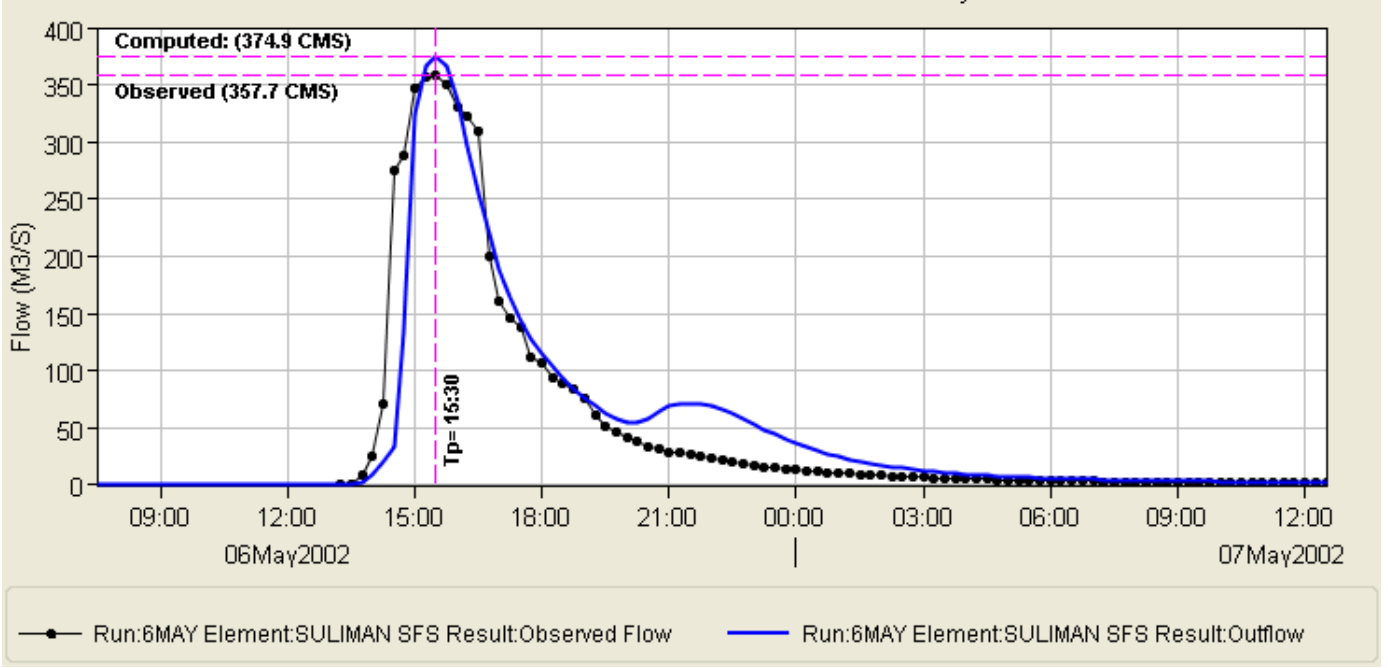

Fig. 7. Observed and simulated flood hydrograph at Sulaiman Bridge for event 6 May 2002.

\section{HESSD}

9, 4747-4775, 2012

\section{Integration of SRTM and TRMM date into the GIS-based hydrological model}

A. Akbari et al.

Title Page

Abstract Introduction

Conclusions

References

Tables

Figures

14

$\rightarrow$ I

4

Back

Close

Full Screen / Esc

Printer-friendly Version

Interactive Discussion 


\section{HESSD}

9, 4747-4775, 2012

\section{Integration of SRTM and TRMM date into the GIS-based hydrological model}

A. Akbari et al.

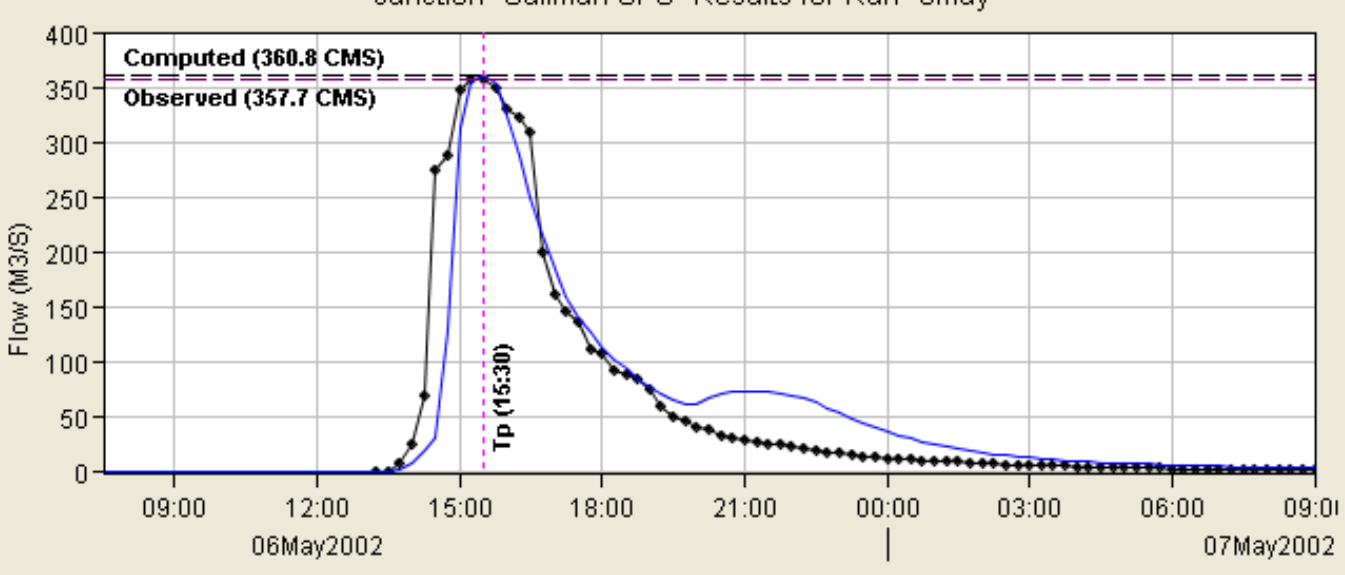

Title Page

Abstract

Introduction

Conclusions

References

Tables

Figures

14

$>$ I

4

Fig. 8. Observed and simulated flood hydrograph resultant from modified-CN for event 6 May at Sulaiman Bridge.

RUn:6MAY Element:SULIMAN SFS Result:Outflom

Back

Close

Full Screen / Esc

Printer-friendly Version

Interactive Discussion 


\section{HESSD}

$9,4747-4775,2012$

\section{Integration of SRTM and TRMM date into the GIS-based hydrological model}

A. Akbari et al.

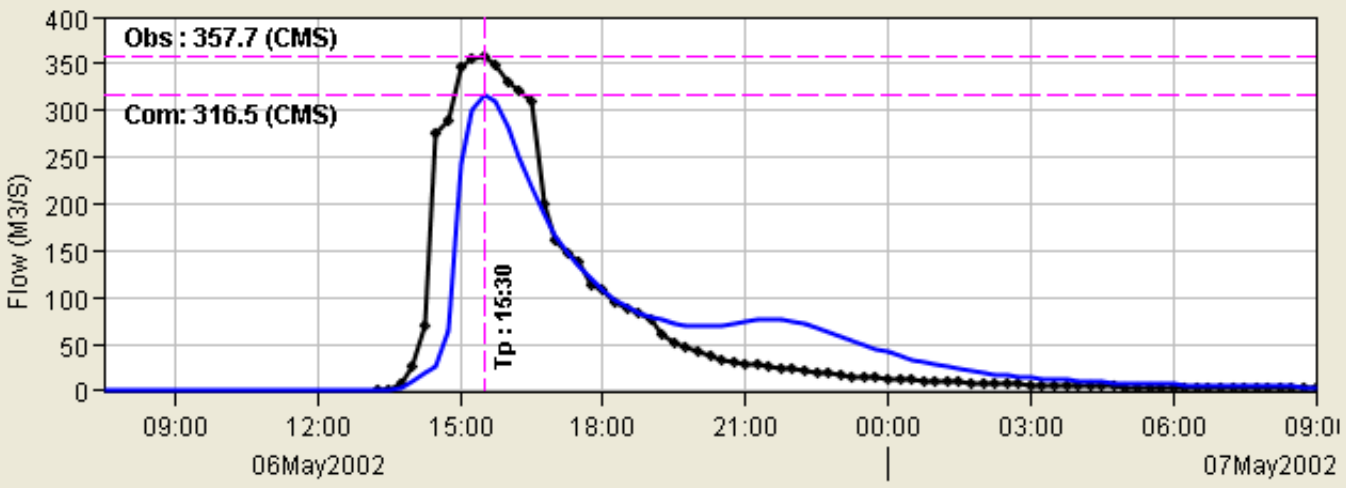

Run:6MAY Element:SULIMAN SFS Result:Obsenued Flom

RUN:6MAY Element:SULIMAN SFS Result:Outflow

Fig. 9. Observed and computed flood hydrograph at Sulaiman Bridge based on SRTM-derived sub-watershed areas.

Title Page

Abstract

Introduction

Conclusions

References

Tables

Figures

14

$>$ I

4

Back

Close

Full Screen / Esc

Printer-friendly Version

Interactive Discussion 


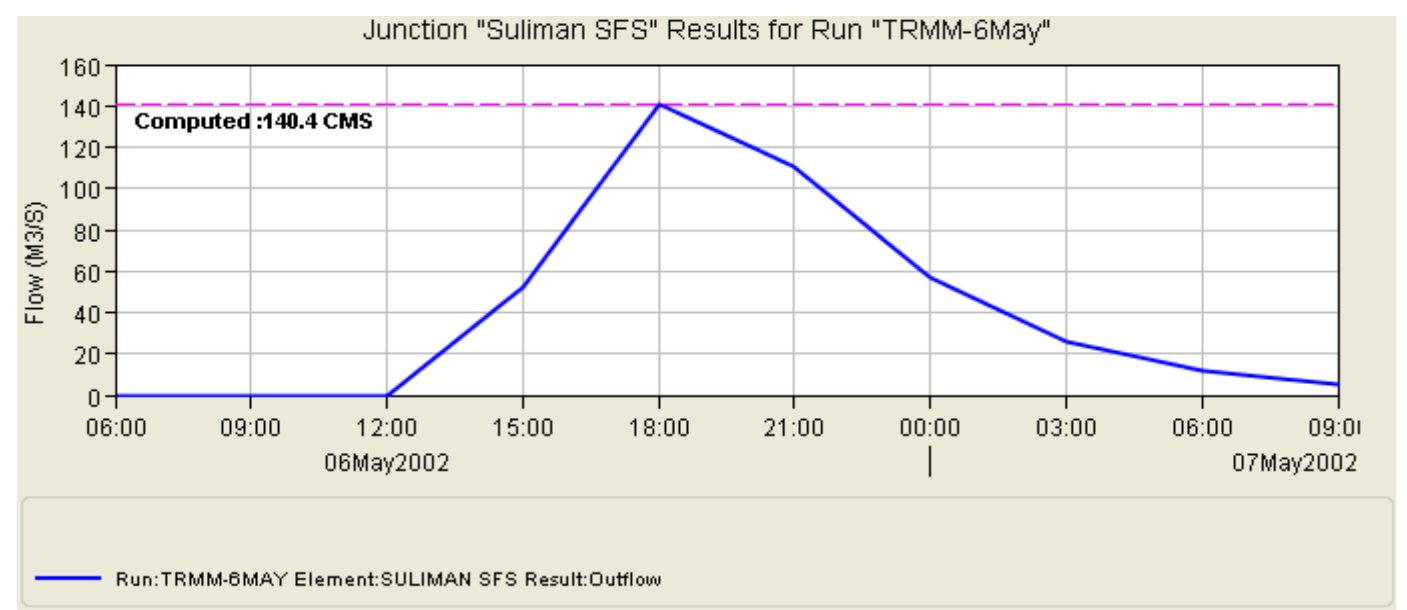

\section{HESSD}

$9,4747-4775,2012$

\section{Integration of SRTM and TRMM date into the GIS-based hydrological model}

A. Akbari et al.

Fig. 10. Computed flood hydrograph for Run4 at Sulaiman Bridge.

Title Page

Abstract

Introduction

Conclusions

References

Tables

Figures

14

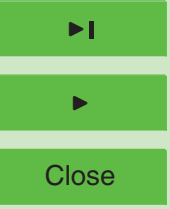

Back

Full Screen / Esc

Printer-friendly Version

Interactive Discussion 


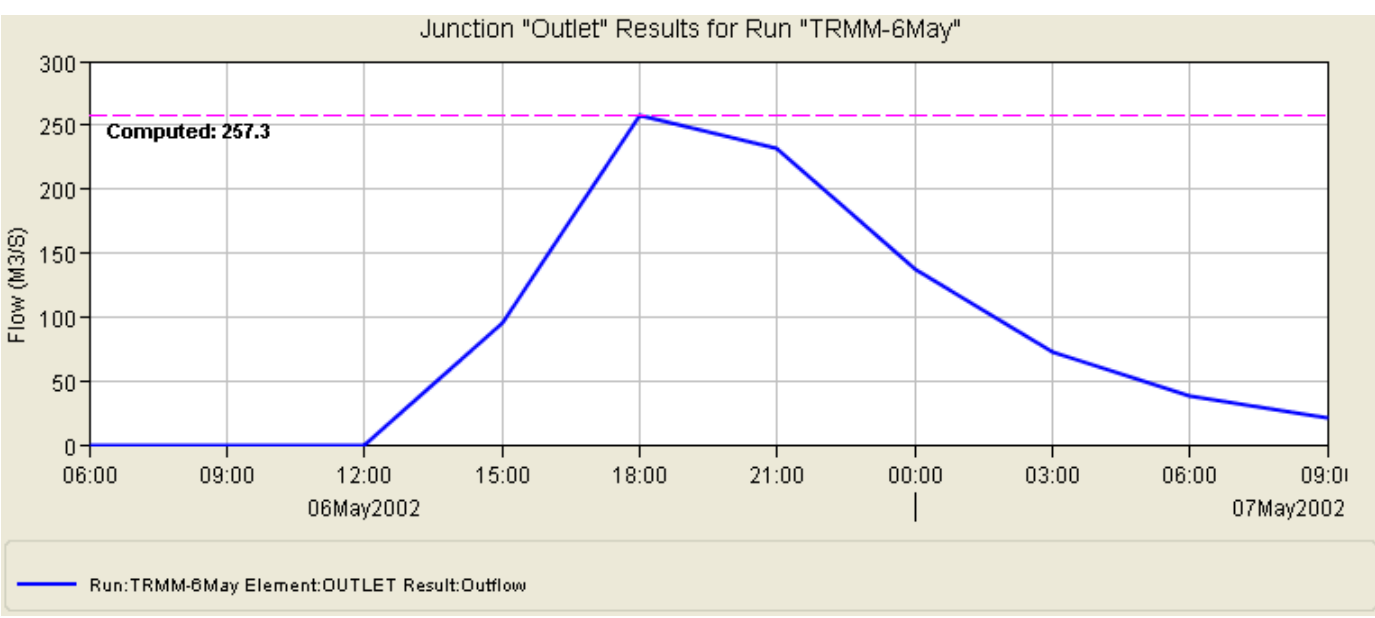

Fig. 11. Computed flow hydrograph resultant from Run5 at the watershed outlet the Sulaiman Bridge.

\section{HESSD}

$9,4747-4775,2012$

\section{Integration of SRTM and TRMM date into the GIS-based hydrological model}

A. Akbari et al.

\section{Title Page}

\section{Abstract}

Introduction

Conclusions

References

Tables

Figures

14

Back

Close

\section{Full Screen / Esc}

Printer-friendly Version

Interactive Discussion 